\title{
Synthesis, Thermal Kinetic Analysis and DFT Calculations of Pyrazine and Pyridine Complexes of Copper(II) Thiocyanate
}

\author{
Hasan NAZIR*1 , Arda ATAKOL ${ }^{2}$, Emine Kübra İNAL'1, Nurcan ACAR¹, Erdal EMİR1, Orhan ATAKOL1 \\ ${ }^{1}$ Ankara University, Science Faculty, Department of Chemistry, 06100, Ankara \\ 2Turkish Standarts Institution, Çayırova, Gebze, Kocaeli
}

(Alınış / Received: 11.03.2018, Kabul / Accepted: 18.04.2018, Online Yayınlanma / Published Online: 27.04.2018)

\section{Keywords}

Thermal kinetic analysis,

KAS,

OFW,

Energetic materials

\begin{abstract}
Two NNN type ligands namely bis-2,6-(pyrazol-1-yl) pyridyne (pp) and bis-2,6-(3,5-dimethyl-pyrazol-1-yl) pyridyne (dmpp) were prepared by the use of 2,6-dichloropyridine, pyrazol and 3,5-dimethylpyrazol. Using these ligands with SCN co-ligand two mononuclear $\mathrm{Cu}(\mathrm{II})$ complexes were synthesized and characterized. The complexes were investigated by thermogravimetry (TG) and differential thermal analysis (DTA) and subjected to isothermal and nonisothermal kinetic analyses. TG and DTA results indicated that the complexes showed two distinctive degradation steps and the NNN type ligand was removed from the structure at temperatures above $300{ }^{\circ} \mathrm{C}$. The activation energies of these complexes and same thermodynamic parameters of these thermal reactions have been calculated. The situation of $\mathrm{d}$ orbitals of $\mathrm{Cu}(\mathrm{II})$ ion, the electron densities of donor atoms of the ligands, natural bond orbital (NBO) analysis, the theoretical IR spectra and HOMO-LUMO energy levels computed by the use of DFT/B3LYP methods with 6-311G (d) basis set in Gaussian 09 software. These data were employed to enlighten the thermal degradation of the complexes prepared.
\end{abstract}

\section{Bakır(II) Tiyosiyanatın Pirazin ve Piridin Komplekslerinin Sentezi, Termal Kinetik Analizi ve DFT Hesaplamaları}

\author{
Anahtar Kelimeler \\ Termal kinetik analiz, \\ KAS, \\ OFW, \\ Enerjik materyaller
}

\begin{abstract}
Özet: 2,6-diklopiridin, pirazol ve 3,5-dimetilpirazol kullanılarak NNN tipinde iki ligand hazırlandı, bis-2,6-(pirazol-1-il) piridin (pp) ve bis-2,6-(3,5-dimetil-pirazol1-il) piridin (dmpp). Bu ligandlar SCN koligandı ile birlikte kullanılarak iki mononuclear $\mathrm{Cu}(\mathrm{II})$ kompleksi sentezlendi ve karakterize edildi. Kompleksler termogravimetri (TG) ve diferansiyel termal analiz (DTA) ile incelendi ve komplekslerin izotermal ve nonizotermal kinetik analizleri yapıldı. TG ve DTA sonuçlarından komplekslerin iki basamaklı olarak parçalandığı, $300{ }^{\circ} \mathrm{C}$ sıcaklığın üzerinde NNN tipi ligandın yapıdan ayrıldığı gözlendi. $\mathrm{Bu}$ termal tepkimelerin aktivasyon enerjileri ve tepkimelerin termodinamik bazı değerleri hesaplandı. Gaussian 09 teorik hesaplama programı içindeki DFT/B3LYP metodu ve 6$311 \mathrm{G}(\mathrm{d})$, temel algoritma seti kullanılarak $\mathrm{Cu}(\mathrm{II})$ iyonunun d orbitallerinin durumu, ligandların donör atomlarının elektron yoğunlukları, NBO analizi, teorik IR spektrumları ve komplekslerin HOMO-LUMO orbitallerinin enerji seviyeleri hesaplandı ve bulunan değerler yardımıyla komplekslerin termal bozunma tepkimeleri yorumland.
\end{abstract}

\section{Introduction}

Bis-2,6-(pyrazol-1-yl) pyridine is NNN type ligand first prepared in 1990. It can be easily synthesized from 2,6-dichloro or bromo pyridine and pyrozole [1]. It is used in place of terpyridine due to its ease of preparation. There were numerous studies regarding to the preparation of mononuclear [2-9], dinuclear and polynuclear [10-19] complexes using this ligand reported in the literature. Apart from co-ligands such as OCN, SCN make two type of bonding to bound the metal complexes to each other [20-22]. OCN and SCN ligands can bound through two atoms due to donors such as $\mathrm{N}, \mathrm{O}$ or $\mathrm{S}$ attached to the carbon atoms or they can establish coordination of two central ions from a single atom due to the probability of resonance 
(Figure 1). If $\mu$-bridges are formed by the coordination of two different central ions with two different atoms it is called end-end coordination and the $\mu$-bridges established by the use of same atoms are known as end-on coordination [23]. The formation of polynuclear coordination compounds is dependent upon the central ion.

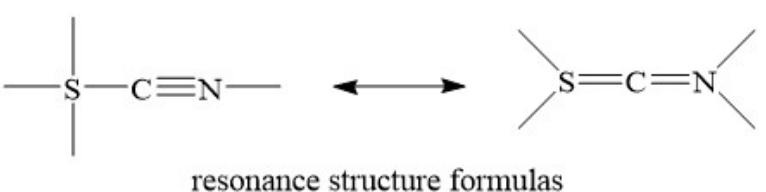<smiles>CN(C)C=C=S(C)C</smiles>

end-end bonding

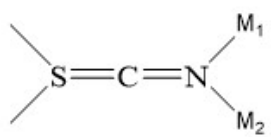

end-on bonding
Figure 1. $\mu$-Bridge type constituted by SCN coligand.

There were two mononuclear $\mathrm{Cu}(\mathrm{II})$ complexes [Cupp(SCN)2] and [Cudmpp(SCN)2] were prepared by the use of bis-2,6(pyrazol-1-yl) pyridine (pp) and bis-2,6(3,5-dimethylpyrazol-1-yl) pyridine (dmpp) with the presence of SCN- ion (Figure 2).

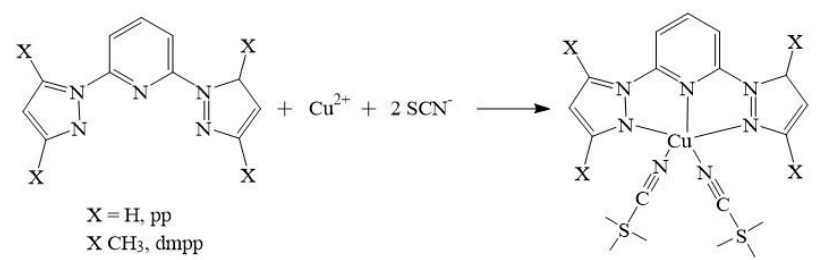

Figure 2. The formulas of the complexes prepared.

The ligands and the complexes prepared were characterized with elemental analysis, IR, mass, ${ }^{1} \mathrm{HNMR}$ and ${ }^{13} \mathrm{CNMR}$ spectra. The X-ray diffraction data and unit cell of [Cudmpp(SCN)2] complexes have been previously reported [9]. The two complexes have been thermo gravimetrically investigated with isothermal (Coats-Redfern, CR) [24, 25] and nonisothermal (Ozawa-Flyn-Wall, OFW) [26, 27] and (Kissinger-Akahira-Sunose, KAS) [28] methods. The activation energy (Ea) and Arhenius pre-exponential factors (A) of the thermal degradation reactions have been determined. The thermal degradation of [Cudmpp(SCN)2] was observed to take place at a higher temperature. The reasons of this have been investigated by the theoretical calculations where the electron densities upon the donor atoms of the ligands were determined by the use of algorithms in Gaussian 09 software [29]. Also the electron densities of the complexes were computed by natural bond orbital (NBO) program in order to have an idea about the thermal stabilities of the complexes. The theoretical and experimental IR data were also compared with each other. HOMO and LUMO levels of the central ions were also calculated.

\section{Material and Method}

\subsection{Apparatus and test procedures}

The IR spectra were taken by the use of Shimadzu Infinity model FTIR apparatus equipped with three reflection ATR unit and all IR spectra were recorded at a resolution of $4 \mathrm{~cm}^{-1}$. C, $\mathrm{H}$ and $\mathrm{N}$ analyses were carried out by Eurovector 3018 CHNS analyzer. $\mathrm{Cu}$ analysis of the complexes were performed by GBC Avanta PM Model flame atomic absorption device. The complex (2-3 mg) was digested in mixture of 1 mL $\mathrm{HNO}_{3}\left(63 \%\right.$, certified) and $1 \mathrm{~mL} \mathrm{H}_{2} \mathrm{O}_{2}$ (30\%) with heating, diluted to $100 \mathrm{~mL}$ and injected to nebulizer of atomic absorpion device for the metal analysis. The NMR spectra of the ligands were recorded with a Varian brand Mercury model $400 \mathrm{MHz}$ NMR spectrophotometer in $\mathrm{d}_{6}$-DMSO. The mass spectra of the ligands were recorded using Shimadzu 2010 Plus GCMS apparatus equipped with Direct Inlet (DI) unit.

The TG-DTA studies were carried out with Shimadzu DTG-60H apparatus. The thermogravimetric analyses were carried out in Pt pans operated at different heating rates under nitrogen atmosphere. The temperature and heat calibrations of both devices were carried out using in and Pb metals. TG method was utilized in the determination of complex stoichiometries at the same time.

Kinetic analyses of each complex were carried out using thermogravimetry at different heating rates. The heating rates employed for both [Cupp(SCN)2] and [Cudmpp(SCN)2] complexes were 5, 10, 15, 20 and $25{ }^{\circ} \mathrm{C} / \mathrm{min}$. The kinetic parameters of KAS and OFW methods were determined using the temperature values at the $0.2-0.4-0.5-0.6$ and 0.8 $\mathrm{g}(\alpha)$ for all heating rates employed in the thermogravimetrical curves. The activation energy and pre-exponential factors were calculated with the help of graphical methods using the pre-determined temperatures according to the KAS and OFW methods. The equations used for graphical calculations for KAS and OFW are as follows [30-32]:

$$
\begin{aligned}
& \ln \frac{\beta}{T^{2}}=\ln \frac{A E_{a}}{\operatorname{Rg}(\alpha)}-\frac{E_{a}}{R T} \\
& \ln \beta=\ln \frac{0.0048 \mathrm{AE}_{\mathrm{a}}}{\operatorname{Rg}(\alpha)}-1.0516 \frac{\mathrm{E}_{\mathrm{a}}}{\mathrm{RT}}
\end{aligned}
$$

The results of Coats-Redfern method were obtained at each heating rate for the $g(\alpha)=0.2,0.4,0.5,0.6,0.8$ separately. In the literature the following formula was used for the graphical calculation of CR method [25].

$\ln \frac{\mathrm{g}(\alpha)}{\mathrm{T}^{2}}=\ln \left[\frac{\mathrm{AR}}{\beta \mathrm{E}_{\mathrm{a}}}\left(1-\frac{2 \mathrm{RT}}{\mathrm{E}_{\mathrm{a}}}\right)\right]-\frac{\mathrm{E}_{\mathrm{a}}}{\mathrm{RT}}$ 
In these equations $\beta$ term shows heating speed as ${ }^{\circ} \mathrm{C}$ $\min ^{-1}, \mathrm{R}$ is the universal gas constant, Ea is thermal disintegration activation energy, A is Arrhenius preexponential factor, $\mathrm{T}$ is temperature in $\mathrm{K}$ and $\mathrm{g}(\alpha)$ is the term which determines completed fraction of thermal disintegration process reaction. These equations are valid only when the reaction order $n$ is equal to one. In all three methods $\ln \beta, \ln [\beta / \mathrm{T} 2]$ and $\ln [g(\alpha) / \mathrm{T} 2]$ are plotted against $1 / \mathrm{T}$ values respectively from which the $\mathrm{Ea}$ and $\mathrm{A}$ values were deduced from the slope and intercept.

Once the Ea and A are calculated, the determination of the some of the thermodynamic parameters becomes a very easy task. If the pre-exponential factor is available the entropy change of activation can approximately be computed by the use of the following formula:

$$
\Delta \mathrm{S}=2.303\left(\log \frac{\mathrm{Ah}}{\mathrm{kT}}\right) \mathrm{R}
$$

where $\mathrm{h}$ and $\mathrm{k}$ are the Planck and Boltzmann constants respectively, $\mathrm{h}=6.626 \times 10^{-34} \mathrm{Js}$ and $\mathrm{k}=1.38 \times 10^{-23} \mathrm{~J} /($ K.molecule). The first law of thermodynamics give the entalphy of the reaction as:

$$
\Delta \mathrm{H}=\mathrm{E}_{\mathrm{a}}-\mathrm{R} \Delta \mathrm{T}
$$

Gibbs Free energy of the thermal reactions can be calculated as $[33,34]$ :

$$
\Delta \mathrm{G}=\Delta \mathrm{H}-\mathrm{T} \Delta \mathrm{S}
$$

\subsection{Theoretical calculations}

Theoretical calculations were carried out by using Gaussian 09W (revision D.01) software. All calculations were performed by DFT/B3LYP/6$31 \mathrm{G}(\mathrm{d})$ method in a gas phase. In addition to the electron densities of the $d$ orbitals of the central ion were determined by the use NBO. The charge density distributions on the ligands were evaluated using DFT. Furthermore, the theoretical IR spectra was deduced and compared with the experimental spectra.

\section{Results}

\section{Preparation of the ligands:}

The ligands, $\mathrm{pp}$ and dmpp, were prepared from pyrazole,3,5-dimethylpyrazole and 2,6-dichloro pyridyne in diglym according to the literature [1].

bis-2,6-(pyrazol-1-yl)pyridyne (pp):, $\mathrm{C}_{11} \mathrm{H}_{9} \mathrm{~N}_{5}$, Yield $\%: 58$, element analysis, calculated \%, C: 62.55; H: 4.29; N: 33.14, Found \%, C: 61.97; H: 4.03; N: 33.41. IR data, $\mathrm{cm}^{-1}: \quad v_{\mathrm{C}-\mathrm{H}(\mathrm{Ar})}:$ 3163-3140-3103-2992, $v_{\mathrm{C}=\mathrm{N}(\text { ring })}: 1607, v_{\mathrm{C}=\mathrm{C}(\text { ring) }}: 1576-1524, v_{\mathrm{C}-\mathrm{N}}: 1456-1392$,
$v_{\mathrm{C}-\mathrm{H}(\mathrm{Ar}):}$ 804-754. ${ }^{1} \mathrm{HNMR}$ data in $\mathrm{d}_{6}-\mathrm{CH}_{3} \mathrm{SOCH}_{3}(\delta$, ppm): $8.85(\mathrm{~d}, 2 \mathrm{H}), 8.16(\mathrm{t}, 1 \mathrm{H}), 7.88(\mathrm{~d}, 2 \mathrm{H}), 7.82(\mathrm{~d}$, $2 \mathrm{H}), 6.64(\mathrm{t}, 2 \mathrm{H}) .{ }^{13} \mathrm{CNMR}$ data in $\mathrm{d}_{6}-\mathrm{CH}_{3} \mathrm{SOCH}_{3}(\delta$, ppm): 149.98, 143.37, 142.90, 128.40, 111.26, 108.84. m/z: 211 (base peak and molecular peak), $184,144,117$.

\section{bis-2,6-(3,5-dimethylpyrazol-1-yl)pyridine}

(dmpp): $\mathrm{C}_{15} \mathrm{H}_{17} \mathrm{~N}_{5}$, Yield\%: 65 , element analysis, calculated \%, C: 67.40; H: 6.41; N: 26.19, Found \%, C: 66.83; H: 6.23; N: 25.74. IR data, $\mathrm{cm}^{-1}: v_{\mathrm{C}-\mathrm{H}(\mathrm{Ar})}$ : 3155-

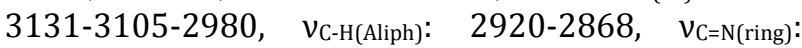
$1603, v_{\mathrm{C}=\mathrm{C}(\text { ring) }}: 1587-1558, v_{\mathrm{CH} 3}: 1473, v_{\mathrm{C}-\mathrm{N}}: 1425-$ 1352, $v_{\mathrm{C}-\mathrm{H}(\mathrm{Ar}):}$ 794-752. ${ }^{1} \mathrm{HNMR}$ data in $\mathrm{d} 6-\mathrm{CH}_{3} \mathrm{SOCH}_{3}$ $(\delta, \mathrm{ppm}): 8.07(\mathrm{t}, 1 \mathrm{H}), 7.68(\mathrm{~d}, 2 \mathrm{H}), 6.12(\mathrm{~s}, 2 \mathrm{H}), 2.56$ $(\mathrm{s}, 6 \mathrm{H}), 2.21(\mathrm{~s}, 6 \mathrm{H}) .{ }^{13} \mathrm{CNMR}$ data in $\mathrm{d} 6-\mathrm{CH}_{3} \mathrm{SOCH}_{3}(\delta$, ppm): 151.44, 149.70, 141.64, 140.84, 113.9s2, 109.50, 14.15, 13.78. m/z: 267 (base peak and molecular peak), 252, 225, 184, 173, 147,95.

\section{Preparation of the complexes:}

Both complexes were synthesized according to the same procedure in $\mathrm{MeOH} / \mathrm{DMF}$ mixture. 0.004 moles of pp or dmpp were dissolved in $25 \mathrm{~mL}$ DMF by heating under constant stirring. To this solution were added a solution of 0.004 mole $\mathrm{CuCl}_{2} .2 \mathrm{H}_{2} \mathrm{O}$ in $25 \mathrm{~mL}$ $\mathrm{MeOH}$ and 0.008 mole $\mathrm{KSCN}$ in $10 \mathrm{~mL}$ hot water. The resulting mixture was left at the bench for 2-3 days and the green-grey crystals were filtered off and dried in air.

Bis-2,6(pyrazol-1-yl)pyridyne $\kappa 3$ NNN-bisthiocya nato $\mathbf{2} \mathbf{N N}$ - copper(II) [Cupp(SCN)2]: $\mathrm{C}_{13} \mathrm{H}_{9} \mathrm{~N}_{7} \mathrm{~S}_{2} \mathrm{Cu}$, Yield \%: 35, element analysis, calculated \%, C:43.52; $\mathrm{H}: 2.53$; N: 27.32; $\mathrm{Cu}: 17.71$. Found \%, C: 43.07; H: 3.09; N: 26.71; Cu: 17.39.IR data, $\mathrm{cm}^{-1}: v_{\mathrm{C}-\mathrm{H}(\mathrm{Ar})}: 3143-$ 3103-3041, $v_{\mathrm{CN}}: 2103, v_{\mathrm{C}=\mathrm{N}(\text { ring) }}: 1624, v_{\mathrm{C}=\mathrm{C}(\text { ring) }}$ : $1589-$ $1526, v_{\mathrm{C}-\mathrm{N}}: 1404, v_{\mathrm{C}-\mathrm{H}(\mathrm{Ar})}: 790-761$.

$\begin{array}{ll}\text { Bis-2,6(3,5-dimethylpyrazol-1-yl)pyridyne } & \kappa 3 \\ \text { NNN-bisthiocyanato } \mathrm{\kappa} 2 \mathrm{NN}- & \text { copper(II) }\end{array}$ [Cudmpp(SCN)2]: $\quad \mathrm{C}_{17} \mathrm{H}_{17} \mathrm{~N}_{7} \mathrm{~S}_{2} \mathrm{Cu}$, Yield \%: 40, element analysis, calculated \%, C: 49.21; $\mathrm{H}: 4.13$; : 23.62; Cu: 5.31. Found \%, C: 48.55; H: 3.87; N: 22.46; $\mathrm{Cu}: 14.69$. IR data, $\mathrm{cm}^{-1}: v_{\mathrm{C}-\mathrm{H}(\mathrm{Ar})}: 3107-3091, v_{\mathrm{C}-\mathrm{H}(\mathrm{Aliph})}$ : 2966-2879, $v_{\mathrm{CN}}: 2064, v_{\mathrm{C}=\mathrm{N}(\text { ring) }}: 1614, v_{\mathrm{C}=\mathrm{C} \text { (ring) }}: 1590-$ $1561, v_{\text {CH3 }}: 1484, v_{\mathrm{C}-\mathrm{N}}: 1415, v_{\mathrm{C}-\mathrm{H}(\mathrm{Ar})}: 771-744$.

\section{TG-DTA results:}

The TG-DTA curves of two complexes are depicted in Figures 3 and 4 and the resulting thermo analytical data are given in Table 1.

\section{Discussion and Conclusion}

Thermogravimetry gives a partial information about the complex stoichiometry. Note that the disintegration of the complexes take place in two distinctive steps. This is more apparent in 


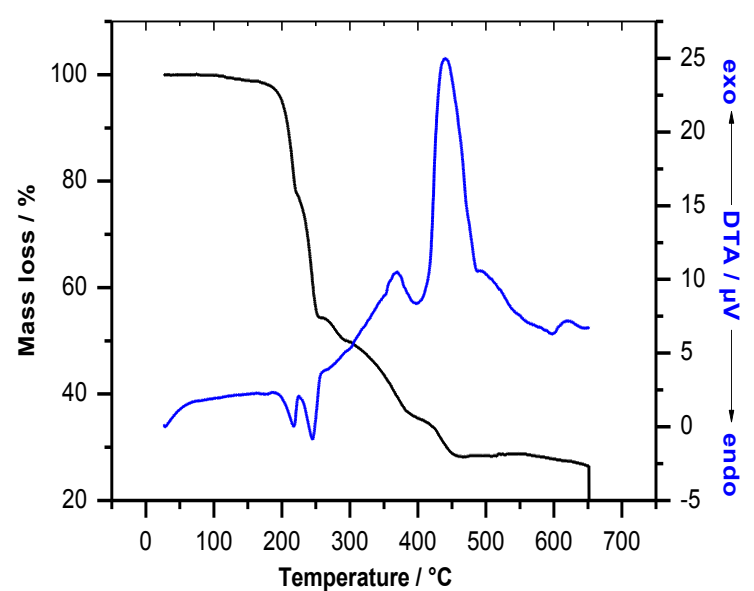

Figure 3. TG-DTA curves of $[\mathrm{Cupp}(\mathrm{SCN}) 2]$, black: TG, blue:DTA curve, heating rate: $10^{\circ} \mathrm{C} / \mathrm{min}$.

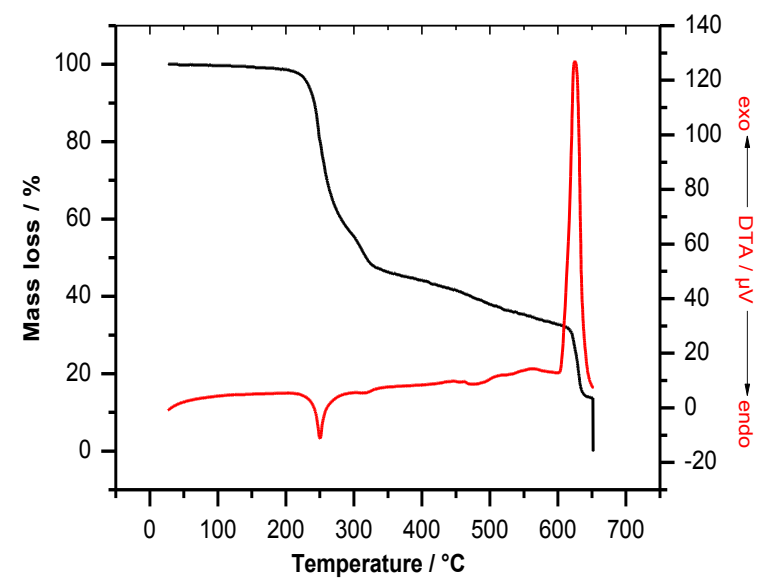

Figure 4. The TG and DTA curves of [Cudmpp(SCN)2], black:TG, red:DTA curve, heating rate: $10^{\circ} \mathrm{C} / \mathrm{min}$.

[Cupp(SCN)2], complex. The data listed in Table 1 reveal that the mass loss in thermal disintegration corresponds to the mass of ligand. The loss of mass after the thermal reactions of 1 . and 2 . is approximately the mass of ligand. While the thermal disintegration of [Cupp(SCN)2] is initiated at complexes between $190-210{ }^{\circ} \mathrm{C}$ the disintegration of [Cudmpp(SCN)2] takes place at a temperature approximately $15^{\circ} \mathrm{C}$ higher than this range. This shows that the [Cudmpp(SCN)2] complex is thermally more stable than [Cupp(SCN)2]. The graphical kinetic analyses result of both complexes by the use of OFW, KAS and CR methods are given in Figure 5a-f and Figure 6a-f respectively.

The activation energies and Arrhenius preexponential factor values computed from the graphs depicted in Figure 5 and 6 are listed in Table 2 and the thermodynamic parameters determined by the use of these values are tabulated in Table 3. As seen from Table 2 activation energy Ea values are comparable to each other. Only the mean value of the 2. thermal reaction of [Cudmpp(SCN)2] complex obtained by the CR method differs from the others. This is most probably due to the fact that the initiation and the completion temperatures of the second thermal reaction of [Cudmpp(SCN)2] complex are not clearly apparent. As seen from Figure 4 the second thermal reaction appears as a shoulder. The data listed in Table 3 reveal the fact that the change of entropy for [Cudmpp(SCN)2] complex accept one result come out to be positive. dmpp ligand contains four aliphatic methyl group. This is an expected outcome since the vibration amplitudes of the methyl groups will be higher with the increasing temperature. The dmpp ligand is more easily dissociated requiring a relatively small activation. Since the ring structure is more robust the dissociation of the pp ligand is more difficult. However, under these circumstances the fact that the initiation of the disintegration of [Cudmpp(SCN)2] complex at temperatures $10-15{ }^{\circ} \mathrm{C}$ higher than [Cupp(SCN)2] cannot be explained by the thermal analysis data. Its activation energy is smaller and entropy changes are more positive but its disintegration temperature is higher. Thermal kinetic analyses data cannot explain this situation. The data listed in Table 1 show that the residue left after the first and the second thermal reactions above $300{ }^{\circ} \mathrm{C}$ is approximately equal to the mass of $\mathrm{Cu}(\mathrm{SCN})_{2}$. In other word the organic ligand above $300{ }^{\circ} \mathrm{C}$ disintegrates in two steps before leaving the structure. The removal of the organic ligand from the structure is most probably related to the strength of the coordination bonds. Although coordination bands are not as strong as the covalent bond they are stronger than dipol-dipol interactions [35]. This may be the prime reason for the removal of dmpp group from the metal ion at higher temperatures. This is a very strong possibility because all the four methyl's are electron donating groups and increase the electron densities of nitrogen donors. This situation is verified by IR spectra. CN three bond stretching band of SCN- ion of pure KSCN is observed at 2038 $\mathrm{cm}-1$ this band appears at $2068 \mathrm{~cm}^{-1}$ for [Cudmpp(SCN)2] and at $2102 \mathrm{~cm}^{-1}$ for [Cupp(SCN)2] complexes. KSCN contains free SCN- ions therefore $\mathrm{CN}$ bond varies between double and triple bonds the vibrational wave number of the triple bond is shifted towards double bond region. The SCN- ions were reported to be bound to $\mathrm{Cu}(\mathrm{II})$ ion with a $\mathrm{N}$ donor for the molecular structure of [Cudmpp(SCN)2] complex obtained with the use of X-ray diffraction data [9]. This situation causes the triple $\mathrm{CN}$ bond in $\mathrm{SCN}^{-}$ion being much more stabile. [Cudmpp(SCN)2] complexes the nitrogen atoms of dmpp ligand possess relatively high electron densities. Therefore, the central $\mathrm{Cu}(\mathrm{II})$ ion withdraws lesser amount of electron in [Cudmpp(SCN)2] complex which causes the $\mathrm{CN}$ vibration band appears at lower energies than [Cupp(SCN)2]. This stabilizes the triple bond between nitrogen and carbon atoms in [Cupp(SCN)2] complex and the vibration wave number shifts towards the triple bonds region. The ligands and the complexes were subjected to theoretical calculations to find the electron densities of the nitrogen donors. 


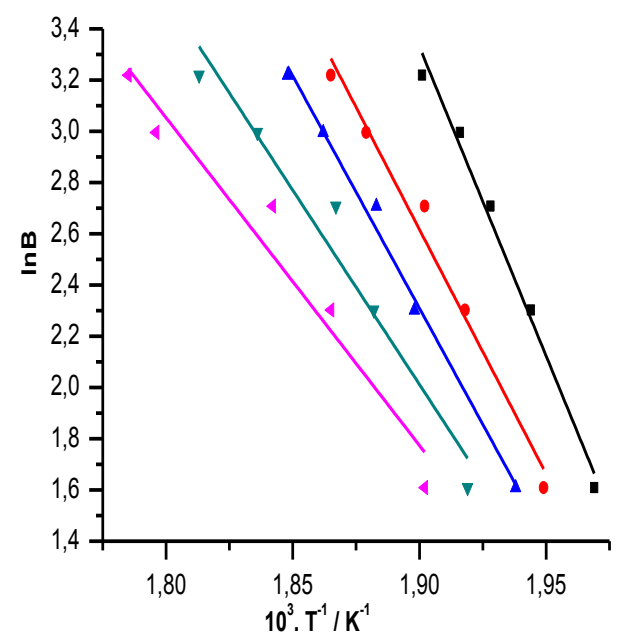

A

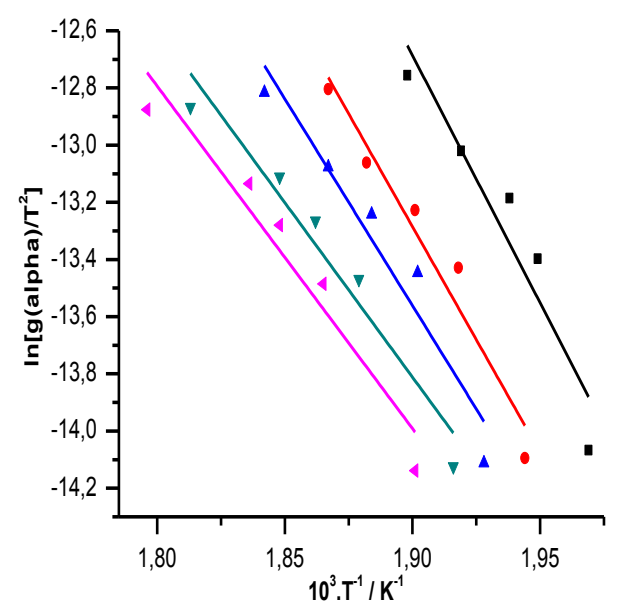

C

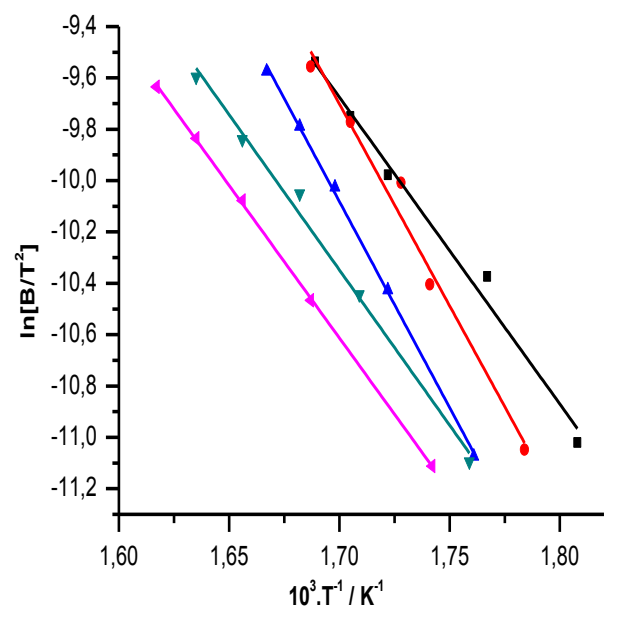

$\mathrm{E}$

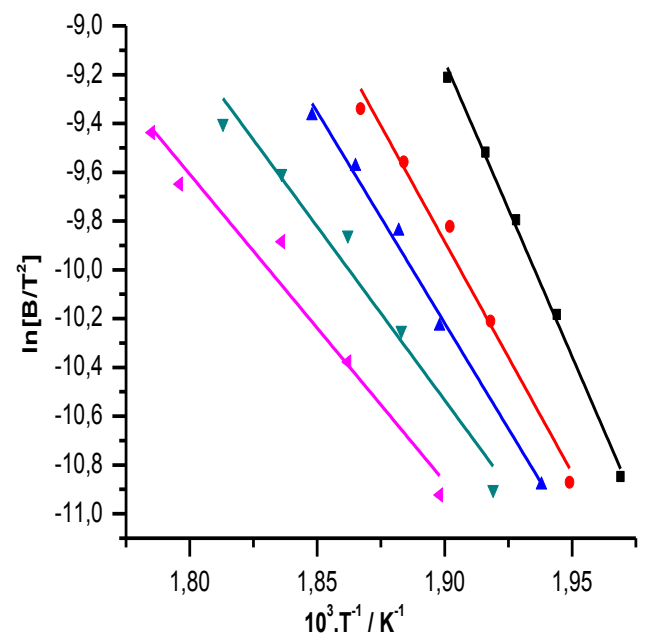

B

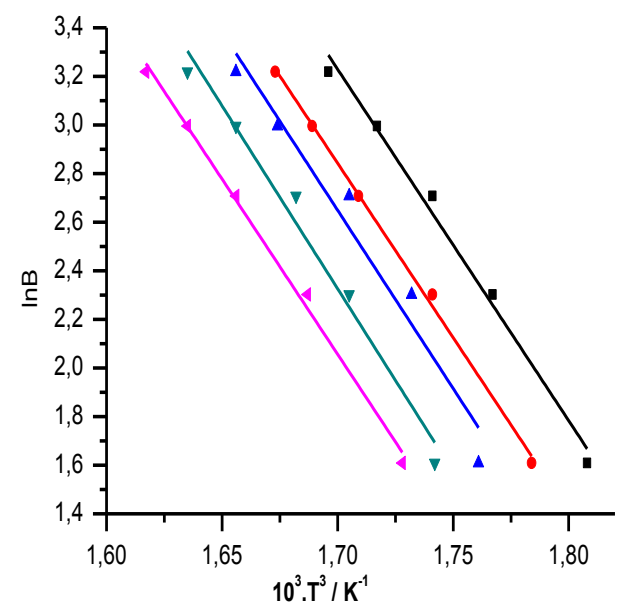

D

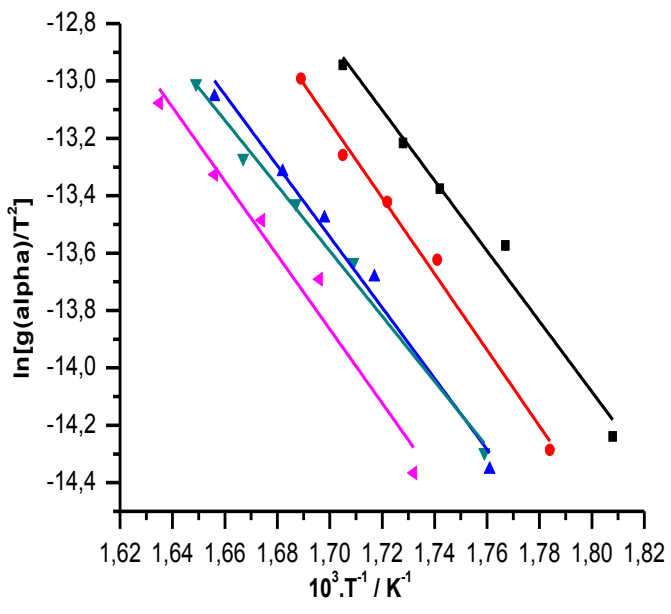

$\mathrm{F}$

Figure 5. The OFW, KAS and CR graphics of first and second thermal reactions of [Cupp(SCN)2] complex, A) OFW of 1. Thermal reaction B) KAS of 1 . Thermal reaction C) CR of 1 . Thermal reaction D) OFW of 2 . Thermal reaction E) KAS of 2. Thermal reaction F) CR of 2. Thermal reaction. 


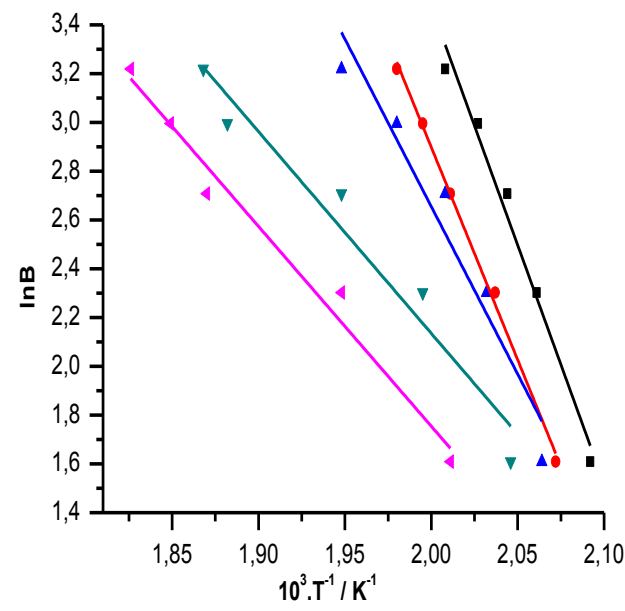

A

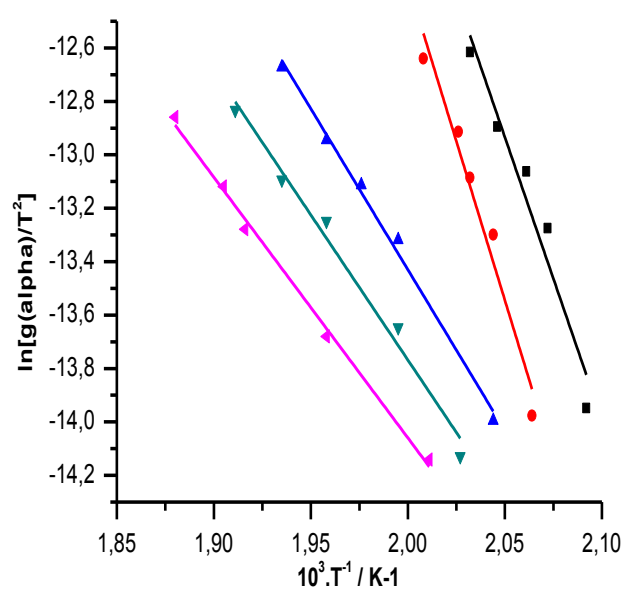

$\mathrm{C}$

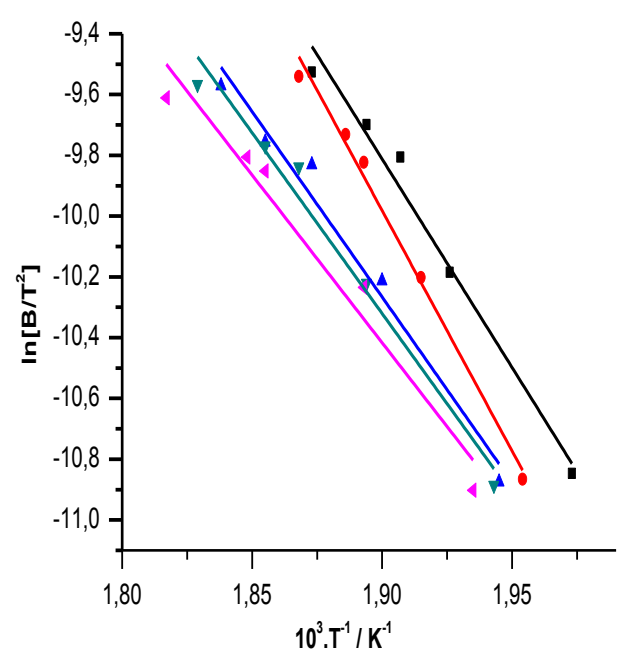

E

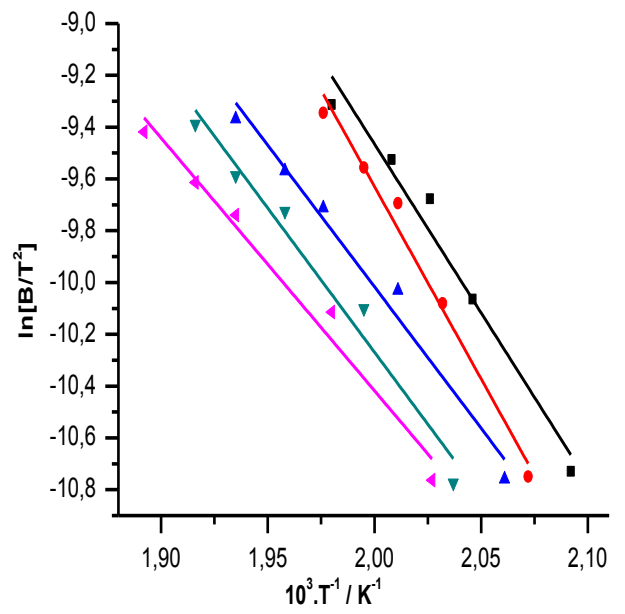

$\mathrm{B}$

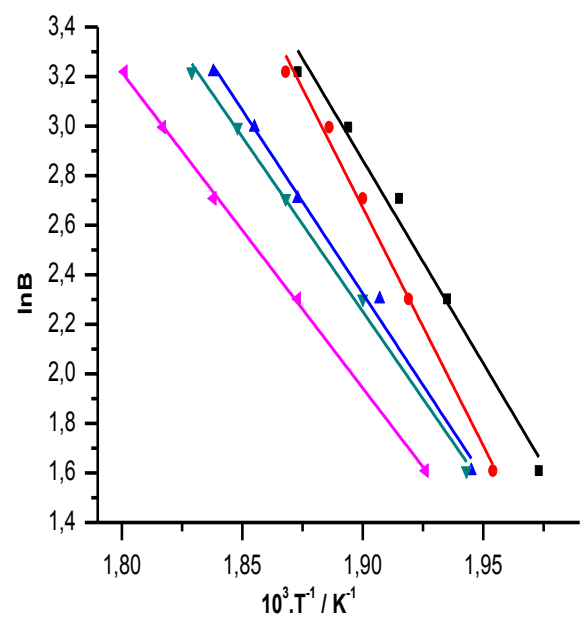

$\mathrm{D}$

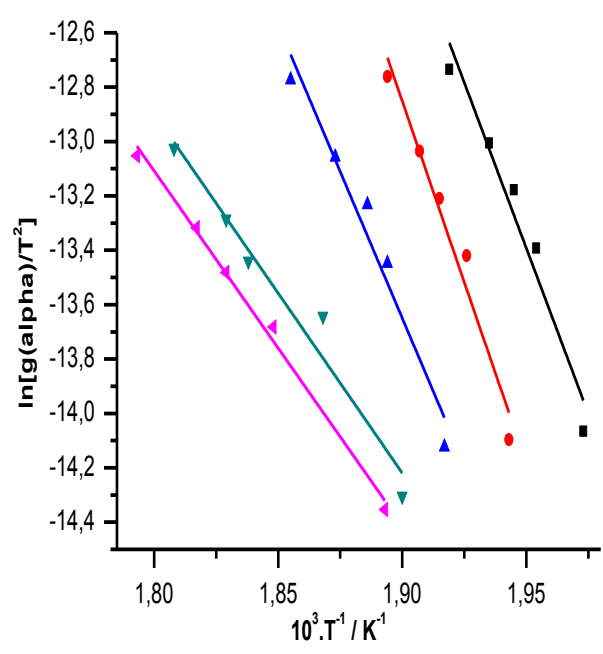

$\mathrm{F}$

Figure 6. The OFW, KAS and CR graphics of first and second thermal reactions of [Cudmpp(SCN)2] complex, A) OFW of 1. Thermal reaction $\quad$ B) KAS of 1 . Thermal reaction C) CR of Thermal reaction D) OFW of 2. Thermal reaction E) KAS of 2. Thermal reaction F) CR of 2 . Thermal reaction. 
Table 1. Thermoanalytic Data of the complexes prepared

\begin{tabular}{|c|c|c|c|c|c|c|}
\hline \multirow{2}{*}{ Complex } & \multicolumn{2}{|c|}{ 1. Thermal Reaction } & \multicolumn{2}{|c|}{ 2. Thermal Reaction } & \multirow{2}{*}{$\begin{array}{l}\text { Total average mass } \\
\text { loss /Calculated } \\
\text { mass loss, \%(The } \\
\text { mass ratio of organic } \\
\text { ligand) }\end{array}$} & \multirow{2}{*}{$\begin{array}{l}\text { Calculated } \\
\text { average } \mathrm{CuO} \\
\text { mass/ found } \\
\text { average } \mathrm{CuO} \\
\text { mass (at } 600 \\
{ }^{\circ} \text { C,under } \mathrm{O}_{2} \text { ) }\end{array}$} \\
\hline & $\begin{array}{l}\text { Temperature } \\
\text { Range, }{ }^{\circ} \mathrm{C}\end{array}$ & $\begin{array}{l}\text { Found } \\
\text { mass loss, \% }\end{array}$ & $\begin{array}{l}\text { Temperature } \\
\text { Range, }{ }^{\circ} \mathrm{C}\end{array}$ & $\begin{array}{l}\text { Found } \\
\text { mass loss, \% }\end{array}$ & & \\
\hline $\begin{array}{l}\text { Cupp }\left((\mathrm{SCN})_{2}\right. \\
5^{\circ} \mathrm{C} / \mathrm{min} . \\
10^{\circ} \mathrm{C} / \mathrm{min} . \\
15^{\circ} \mathrm{C} / \mathrm{min} . \\
20^{\circ} \mathrm{C} / \mathrm{min} . \\
25^{\circ} \mathrm{C} / \mathrm{min} \text {. }\end{array}$ & $\begin{array}{l}191-224 \\
197-230 \\
199-241 \\
203-288 \\
213-296\end{array}$ & $\begin{array}{l}18.42 \\
20.71 \\
20.47 \\
27.63 \\
38.54\end{array}$ & $\begin{array}{l}224-255 \\
230-288 \\
241-295 \\
288-370 \\
296-371\end{array}$ & $\begin{array}{l}25.10 \\
27.02 \\
28.68 \\
22.67 \\
15.76\end{array}$ & $\begin{array}{l}43.52 \\
47.73 \\
49.15 \\
50.30 \\
54.30 \\
\text { Average:49.00 } \pm 3.91 \\
\text { Calculated:54.04 } \\
\end{array}$ & $\begin{array}{l}20.35 \\
19.77 \pm 1.66\end{array}$ \\
\hline $\begin{array}{l}\text { Cudmpp }(\mathrm{SCN})_{2} \\
5^{\circ} \mathrm{C} / \mathrm{min} . \\
10^{\circ} \mathrm{C} / \mathrm{min} . \\
15^{\circ} \mathrm{C} / \mathrm{min} . \\
20^{\circ} \mathrm{C} / \mathrm{min} . \\
25^{\circ} \mathrm{C} / \mathrm{min} .\end{array}$ & $\begin{array}{l}173-268 \\
204-281 \\
215-290 \\
218-293 \\
227-298\end{array}$ & $\begin{array}{l}37.53 \\
39.00 \\
38.22 \\
38.61 \\
39.41\end{array}$ & $\begin{array}{l}268-336 \\
281-348 \\
290-363 \\
293-270 \\
298-376\end{array}$ & $\begin{array}{l}15.32 \\
15.22 \\
16.41 \\
17.39 \\
18.30\end{array}$ & $\begin{array}{l}52.85 \\
54.22 \\
54.63 \\
55.00 \\
57.71 \\
\text { Average:54.88 } \pm 2.11 \\
\text { Calculated:59.82 } \\
\end{array}$ & $\begin{array}{l}17.80 \\
16.58 \pm 0.74\end{array}$ \\
\hline
\end{tabular}

Table 2. The results of graphical calculations from OFW, KAS and CR graphics of the complexes prepared

\begin{tabular}{|c|c|c|c|c|c|c|}
\hline \multirow{2}{*}{ Complex } & \multicolumn{2}{|c|}{ OFW } & \multicolumn{2}{|c|}{ KAS } & \multicolumn{2}{|c|}{ CR } \\
\hline & Ea (kJ/mol) & $\mathrm{A}\left(\mathrm{min} .^{-1}\right)$ & Ea $(\mathrm{kJ} / \mathrm{mol})$ & $\mathrm{A}\left(\mathrm{min} .^{-1}\right)$ & $\mathrm{Ea}(\mathrm{kJ} / \mathrm{mol})$ & $\mathrm{A}\left(\mathrm{min} .^{-1}\right)$ \\
\hline $\begin{array}{l}{[\mathrm{Cupp}(\mathrm{SCN}) 2]} \\
1 . \text { Thermal } \\
\text { reaction }\end{array}$ & $\begin{array}{l}\mathrm{g}(\alpha)=0.2 \\
200.59 \pm 2.81 \\
\mathrm{R}=0.9928 \\
\mathrm{~g}(\alpha)=0.4 \\
158.64 \pm 2.30 \\
\mathrm{R}=0.9885 \\
\mathrm{~g}(\alpha)=0.5 \\
150.79 \pm 1.32 \\
\mathrm{R}=0.9953 \\
\mathrm{~g}(\alpha)=0.6 \\
126.11 \pm 2.24 \\
\mathrm{R}=0.9730 \\
\mathrm{~g}(\alpha)=0.8 \\
106.34 \pm 1.70 \\
\mathrm{R}=0.9685 \\
\text { MEAN: } \\
\mathbf{1 4 8 . 4 9} \pm \mathbf{3 6 . 0 3}\end{array}$ & $\begin{array}{l}3.91 \pm 0.1110^{18} \\
3.33 \pm 0.0910^{14} \\
5.50 \pm 0.0910^{13} \\
2.02 \pm 0.0710^{11} \\
2.75 \pm 0.0810^{9}\end{array}$ & $\begin{array}{l}g(\alpha)=0.2 \\
201.05 \pm 1.48 \\
R=0.9981 \\
g(\alpha)=0.4 \\
157.68 \pm 2.06 \\
R=0.9904 \\
g(\alpha)=0.5 \\
143.93 \pm 1.22 \\
R=0.9951 \\
g(\alpha)=0.6 \\
118.25 \pm 1.67 \\
R=0.9805 \\
g(\alpha)=0.8 \\
104.81 \pm 1.39 \\
R=0.9781 \\
\text { MEAN: } \\
\text { 145.14 } \mathbf{3 8 . 9 6}\end{array}$ & $\begin{array}{l}1.16 \pm 0.0210^{21} \\
4.32 \pm 0.1110^{16} \\
1.83 \pm 0.0310^{15} \\
4.13 \pm 0.1110^{12} \\
1.52 \pm 0.0410^{11}\end{array}$ & $\begin{array}{l}\theta=5 \\
143.90 \pm 4.56 \\
R=0.9371 \\
\theta=10 \\
131.41 \pm 2.62 \\
R=0.9690 \\
\theta=15 \\
120.26 \pm 2.55 \\
R=0.9585 \\
\theta=20 \\
101.53 \pm 1.62 \\
R=0.9656 \\
\theta=25 \\
99.59 \pm 1.80 \\
R=0.9559 \\
\text { MEAN: } \\
\mathbf{1 1 9 . 3 4} \pm \mathbf{1 9 . 0 0}\end{array}$ & $\begin{array}{l}5.12 \pm 0.31 \\
10^{13} \\
\\
2.96 \pm 0.11 \\
10^{12} \\
2.41 \pm 0.10 \\
10^{11} \\
2.92 \pm 0.09 \\
10^{9} \\
1.93 \pm 0.06 \\
10^{9}\end{array}$ \\
\hline $\begin{array}{l}{[\mathrm{Cupp}(\mathrm{SCN}) 2]} \\
2 . \text { Thermal } \\
\text { reaction }\end{array}$ & $\begin{array}{l}\mathrm{g}(\alpha)=0.2 \\
120.24 \pm 0.97 \\
\mathrm{R}=0.9937 \\
\mathrm{~g}(\alpha)=0.4 \\
119.34 \pm 0.44 \\
\mathrm{R}=0.9986 \\
\mathrm{~g}(\alpha)=0.5 \\
121.96 \pm 2.04 \\
\mathrm{R}=0.9745 \\
\mathrm{~g}(\alpha)=0.6 \\
125.19 \pm 1.48 \\
\mathrm{R}=0.9877 \\
\mathrm{~g}(\alpha)=0.8 \\
119.88 \pm 0.65 \\
\mathrm{R}=0.9972 \\
\text { MEAN: } \\
\mathbf{1 2 1 . 3 2} \pm \mathbf{2 . 3 5}\end{array}$ & $\begin{array}{l}1.66 \pm 0.0210^{7} \\
1.89 \pm 0.0110^{7} \\
3.26 \pm 0.0910^{7} \\
6.66 \pm 0.1310^{7} \\
1.92 \pm 0.0210^{7}\end{array}$ & $\begin{array}{l}\mathrm{g}(\alpha)=0.2 \\
99.36 \pm 0.72 \\
\mathrm{R}=0.9926 \\
\mathrm{~g}(\alpha)=0.4 \\
130.70 \pm 1.62 \\
\mathrm{R}=0.9877 \\
\mathrm{~g}(\alpha)=0.5 \\
133.46 \pm 0.38 \\
\mathrm{R}=0.9993 \\
\mathrm{~g}(\alpha)=0.6 \\
100.55 \pm 0.58 \\
\mathrm{R}=0.9955 \\
\mathrm{~g}(\alpha)=0.8 \\
98.80 \pm 0.10 \\
\mathrm{R}=0.9998 \\
\text { MEAN: } \\
\mathbf{1 1 2 . 5 7} \pm \mathbf{2 1 . 4 2}\end{array}$ & $\begin{array}{l}2.50 \pm 0.0310^{9} \\
3.89 \pm 0.0810^{12} \\
7.15 \pm 0.0410^{12} \\
6.59 \pm 0.0610^{9} \\
4.34 \pm 0.0110^{9}\end{array}$ & $\begin{array}{l}\theta=5 \\
101.99 \pm 1.01 \\
R=0.9893 \\
\theta=10 \\
110.19 \pm 0.74 \\
R=0.9948 \\
\theta=15 \\
102.81 \pm 0.85 \\
R=0.9747 \\
\theta=20 \\
94.54 \pm 0.57 \\
R=0.9943 \\
\theta=25 \\
107.15 \pm 1.30 \\
R=0.9802 \\
\text { MEAN: } \\
\mathbf{1 0 3 . 3 4} \pm 5.97\end{array}$ & $\begin{array}{l}1.82 \pm 0.03 \\
10^{8} \\
1.58 \pm 0.02 \\
10^{9} \\
3.23 \pm 0.05 \\
10^{8} \\
7.06 \pm 0.07 \\
10^{7} \\
1.00 \pm 0.02 \\
10^{9}\end{array}$ \\
\hline
\end{tabular}




\begin{tabular}{|c|c|c|c|c|c|c|}
\hline $\begin{array}{l}\text { [Cudmpp(SC } \\
\text { N)2] } \\
\text { 1. Thermal } \\
\text { reaction }\end{array}$ & $\begin{array}{l}\mathrm{g}(\alpha)=0.2 \\
145.03 \pm 0.77 \\
\mathrm{R}=0.9981 \\
\mathrm{~g}(\alpha)=0.4 \\
108.65 \pm 2.07 \\
\mathrm{R}=0.9628 \\
\mathrm{~g}(\alpha)=0.5 \\
68.78 \pm 0.70 \\
\mathrm{R}=0.99703 \\
\mathrm{~g}(\alpha)=0.6 \\
68.11 \pm 0.46 \\
\mathrm{R}=0.9867 \\
\mathrm{~g}(\alpha)=0.8 \\
162.73 \pm 2.34 \\
R=0.9893 \\
\text { MEAN: } \\
\mathbf{1 1 0 . 7 6} \pm \mathbf{4 5 . 5 8}\end{array}$ & $\begin{array}{l}3.94 \pm 0.1010^{4} \\
3.35 \pm 0.0710^{6} \\
1.74 \pm 0.0310^{3} \\
2.43 \pm 0.0510^{3} \\
76.27 \pm 1.22\end{array}$ & $\begin{array}{l}\mathrm{g}(\alpha)=0.2 \\
108.43 \pm 1.36 \\
\mathrm{R}=0.9815 \\
\mathrm{~g}(\alpha)=0.4 \\
123.50 \pm 1.29 \\
\mathrm{R}=0.9900 \\
\mathrm{~g}(\alpha)=0.5 \\
90.83 \pm 0.80 \\
\mathrm{R}=0.9870 \\
\mathrm{~g}(\alpha)=0.6 \\
92.48 \pm 0.98 \\
\mathrm{R}=0.9762 \\
\mathrm{~g}(\alpha)=0.8 \\
81.14 \pm 0.66 \\
\mathrm{R}=0.9859 \\
\text { MEAN: } \\
\mathbf{9 9 . 2 8} \pm 16.90\end{array}$ & $\begin{array}{l}7.93 \pm 0.1210^{13} \\
6.69 \pm 0.1310^{10} \\
5.94 \pm 0.1110^{10} \\
9.38 \pm 0.1210^{9}\end{array}$ & $\begin{array}{l}\theta=5 \\
176.12 \pm 4.80 \\
R=0.9683 \\
\theta=10 \\
197.795 .02 \\
R=0.9777 \\
\theta=15 \\
100.16 \pm 0.52 \\
R=0.9962 \\
\theta=20 \\
90.28 \pm 0.69 \\
R=0.9901 \\
\theta=25 \\
81.14 \pm 0.29 \\
R=0.9972 \\
\text { MEAN: } \\
\mathbf{1 2 9 . 0 9 \pm 5 3 . 6 2}\end{array}$ & $\begin{array}{l}1.85 \pm 0.10 \\
10^{18} \\
4.72 \pm 0.24 \\
10^{20} \\
4.29 \pm 0.05 \\
10^{9} \\
6.15 \pm 00.09 \\
10^{8} \\
5.74 \pm 00.05 \\
10^{7}\end{array}$ \\
\hline $\begin{array}{l}\text { [Cudmpp(SC } \\
\text { N)2] } \\
\text { 2. Thermal } \\
\text { reaction }\end{array}$ & $\begin{array}{l}\mathrm{g}(\alpha)=0.2 \\
136.42 \pm 1.46 \\
\mathrm{R}=0.9916 \\
\mathrm{~g}(\alpha)=0.4 \\
159.72 \pm 1.35 \\
\mathrm{R}=0.9960 \\
\mathrm{~g}(\alpha)=0.5 \\
123.07 \pm 0.82 \\
\mathrm{R}=0.9959 \\
\mathrm{~g}(\alpha)=0.6 \\
117.16 \pm 0.54 \\
\mathrm{R}=0.9979 \\
\mathrm{~g}(\alpha)=0.8 \\
105.98 \pm 0.20 \\
\mathrm{R}=0.99975 \\
\text { MEAN: } \\
\mathbf{1 2 8 . 0 7} \pm \mathbf{2 1 . 5 1}\end{array}$ & $\begin{array}{l}1.54 \pm 0.0310^{12} \\
5.36 \pm 0.0910^{14} \\
2.13 \pm 0.0310^{11} \\
3.58 \pm 0.0410^{10} \\
3.01 \pm 0.0110^{9}\end{array}$ & $\begin{array}{l}g(\alpha)=0.2 \\
114.12 \pm 1.22 \\
R=0.9879 \\
g(\alpha)=0.4 \\
131.61 \pm 1.06 \\
R=0.9948 \\
g(\alpha)=0.5 \\
101.46 \pm 1.05 \\
R=0.9856 \\
g(\alpha)=0.6 \\
98.86 \pm 0.99 \\
R=0.99860 \\
g(\alpha)=0.8 \\
91.77 \pm 0.17 \\
R=0.9749 \\
\text { MEAN: } \\
\text { 107.56 } 15.84\end{array}$ & $\begin{array}{l}7.96 \pm 0.1610^{11} \\
8.44 \pm 0.1310^{13} \\
7.47 \pm 0.1510^{10} \\
5.08 \pm 0.0910^{10} \\
1.06 \pm 0.0210^{10}\end{array}$ & $\begin{array}{l}\theta=5 \\
202,46 \pm 5.81 \\
R=0.9728 \\
\theta=10 \\
226.85 \pm 6 i 29 \\
R=0.9788 \\
\theta=15 \\
179.11 \pm 4.29 \\
R=0.9746 \\
\theta=20 \\
109.96 \pm 1.60 \\
R=0.9762 \\
\theta=25 \\
108.39 \pm 0.61 \\
R=0.99963 \\
\text { MEAN: } \\
\text { 165.35 } \pm \mathbf{5 4 . 0 2}\end{array}$ & $\begin{array}{l}7.80 \pm 0.44 \\
10^{19} \\
6.88 \pm 0.37 \\
10^{20} \\
2.28 \pm 0.11 \\
10^{12} \\
1.45 \pm 0.04 \\
10^{10} \\
1,03 \pm 0.01 \\
10^{10}\end{array}$ \\
\hline
\end{tabular}

Table 3. The calculated thermodynamic values of the complexes for first and second thermal reactions.

\begin{tabular}{|c|c|c|c|c|c|c|c|c|c|}
\hline \multirow{3}{*}{ Complex } & \multicolumn{9}{|c|}{ Methods } \\
\hline & \multicolumn{3}{|c|}{ OFW } & \multicolumn{3}{|c|}{ KAS } & \multicolumn{3}{|c|}{ Coats-Redfern } \\
\hline & $\begin{array}{l}\Delta \mathrm{H} \\
(\mathrm{kJ} / \text { mole })\end{array}$ & $\begin{array}{l}\Delta \mathrm{S} \\
(\mathrm{J} / \mathrm{K})\end{array}$ & $\begin{array}{l}\Delta \mathrm{G} \\
(\mathrm{kJ} / \text { mole })\end{array}$ & $\begin{array}{l}\Delta \mathrm{H} \\
(\mathrm{kJ} / \text { mole })\end{array}$ & $\begin{array}{l}\Delta \mathrm{S} \\
(\mathrm{J} / \mathrm{K})\end{array}$ & $\begin{array}{l}\Delta \mathrm{G} \\
(\mathrm{kJ} / \text { mole })\end{array}$ & $\begin{array}{l}\Delta \mathrm{H} \\
(\mathrm{kJ} / \text { mole })\end{array}$ & $\begin{array}{l}\Delta \mathrm{S} \\
(\mathrm{J} / \mathrm{K})\end{array}$ & $\begin{array}{l}\Delta \mathrm{G} \\
(\mathrm{kJ} / \text { mole })\end{array}$ \\
\hline $\begin{array}{l}{\left[\mathrm{Cupp}(\mathrm{SCN})_{2}\right]} \\
\text { 1.Thermal } \\
\text { reaction }\end{array}$ & 148.49 & 29.05 & 142.99 & 145.14 & 69.01 & 132.09 & 119.34 & $\begin{array}{l}- \\
10.22\end{array}$ & 121.27 \\
\hline $\begin{array}{l}\left.\text { Cupp }(\mathrm{SCN})_{2}\right] \\
\text { 2.Thermal } \\
\text { reaction }\end{array}$ & 121.32 & $\begin{array}{l}- \\
110.4 \\
3 \\
\end{array}$ & 147.27 & 112.57 & -8.70 & 114.61 & 103.34 & $\begin{array}{l}- \\
71.75\end{array}$ & 120.20 \\
\hline $\begin{array}{l}{\left[\text { Cudmpp }(\mathrm{SCN})_{2}\right]} \\
\text { 1.Thermal } \\
\text { reaction }\end{array}$ & 110.76 & $\begin{array}{l}- \\
124.0 \\
7\end{array}$ & 137.93 & 9928 & 17.12 & 95.53 & 129.99 & $\begin{array}{l}146.8 \\
3\end{array}$ & 114.67 \\
\hline $\begin{array}{l}{\left[\mathrm{Cudmpp}(\mathrm{SCN})_{2}\right]} \\
\text { 2.Thermal } \\
\text { reaction }\end{array}$ & 128.07 & 31.28 & 118.99 & 107.56 & 16.06 & 102.89 & 165.54 & $\begin{array}{l}148.4 \\
0\end{array}$ & 122.50 \\
\hline
\end{tabular}

The images of HOMO-LUMO orbitals of [Cupp(SCN)2] and [Cudmpp(SCN)2] complexes are depicted in Figure 7 and Figure 8. There were two different probabilities of LUMO orbitals of [Cudmpp(SCN)2] complex. This situation is apparent in Figure 8 if the program is used in two different $\alpha$ and $\beta$ modes. As seen from this figure both the organic ligand and thiocyanide ions contribute to the LUMO and HOMO energies of [Cupp(SCN)2] complex. On the other hand in the alpha and beta forms of [Cudmpp(SCN)2] complex only thiocyanate ion contributes to the formation of homo levels. The formation of LUMO level was contributed by the organic ligand in $\alpha$ and $\beta$ form and the thiocyanate ion. In [Cudmpp(SCN)2] complex the fact that the greater contribution of the organic ligand to LUMO levels in $\alpha$ form can be interpreted as the electrons on nitrogen donors were largely transferred to the C(II) ion. That is why there is no electron transfer to the high energy molecular orbitals. The fact that the high energy molecular orbitals are empty means that there will be an electron transfer to empty high orbitals from $\pi$ systems between the carbon atoms of the thiocyanide ions and the triple bond between the carbon and 
nitrogen atoms in [Cudmpp(SCN)2] complex are weakened compared to [Cupp(SCN)2] complex. The triple bond is more rigid in [Cupp(SCN)2] complexes. In previous studies the coordination sphere of [Cudmpp(SCN)2] complex is between square and triangular bi pyramidal structure [36]. This result is found by a simple formula as follows:

$$
\tau=(\alpha-\beta) / 60
$$

( $\alpha$ and $\beta$ are the two biggest angles in coordination spheres). If the result of this formula is 0 the coordination sphere is square pyramidal. If it comes to be 1 then the structure is most likely to be triangular pyramidal. The real value is given as 0.498 which is approximately at the middle. That is why five nitrogen donors cannot be placed at the axis around the $\mathrm{Cu}(\mathrm{II})$ central ion. However, if we assume that thiocyanide ions are located at a very close proximity of $\mathrm{z}$ axis, the occupancy value of $\mathrm{dz}^{2}$ orbital value of [Cupp(SCN)2] complex is markedly higher. Table 4 lists $d$ orbital occupancy values of $\mathrm{Cu}(\mathrm{II})$ ion.

Table 4. The occuppacies of the central $\mathrm{Cu}(\mathrm{II})$ ions of the complexes calculated from nbo program.

\begin{tabular}{|l|c|c|}
\hline Orbital & {$[$ Cupp(SCN)2] } & [Cudmpp(SCN)2] \\
\hline $\mathrm{dxy}$ & 1.88690 & 1.97567 \\
\hline $\mathrm{dyz}$ & 1.97403 & 1.76669 \\
\hline $\mathrm{dzx}$ & 1.92411 & 1.98165 \\
\hline $\mathrm{dz}^{2}$ & 1.95302 & 1.97275 \\
\hline $\mathrm{dx}^{2}-\mathrm{y}^{2}$ & 1.59524 & 1.52684 \\
\hline
\end{tabular}
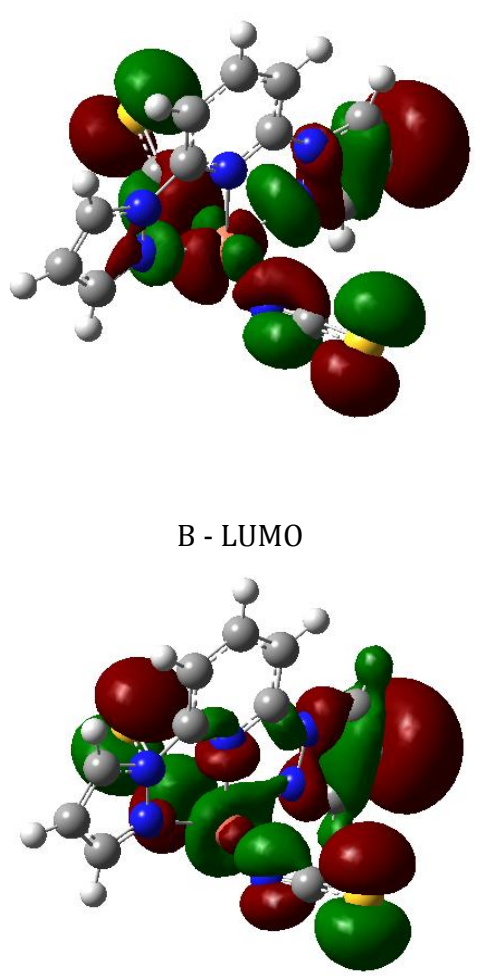

A - HOMO

Figure 7. A) HOMO and B) LUMO orbitals of the [Cupp(SCN)2] complex.
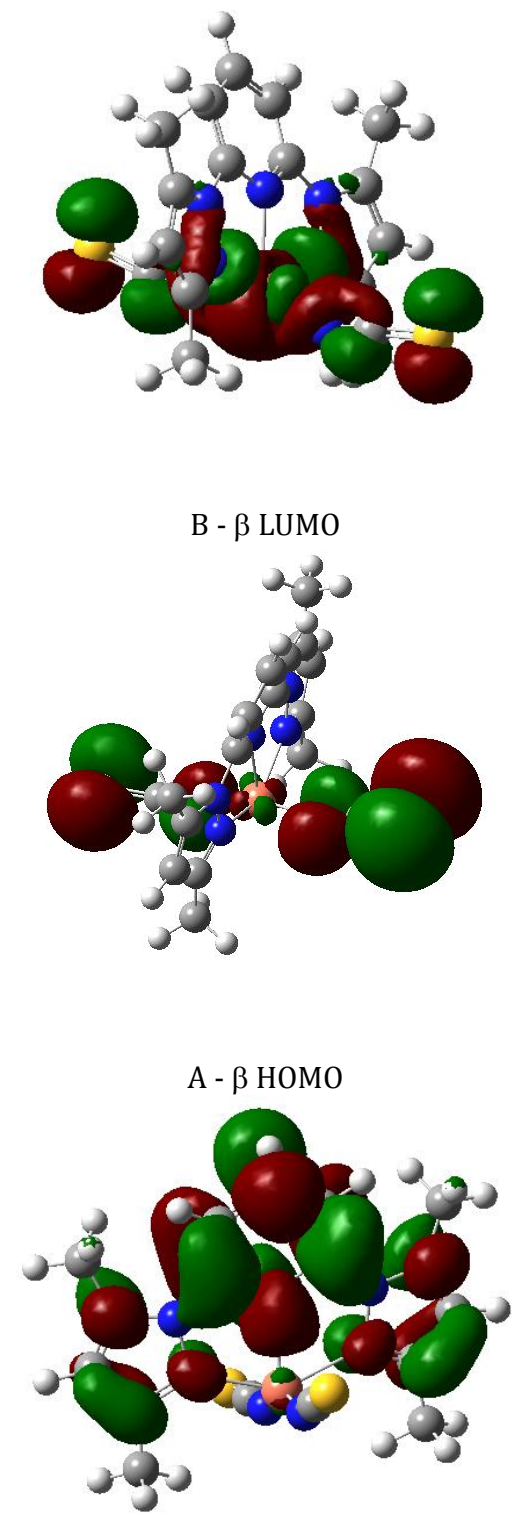

B - $\alpha$ LUMO

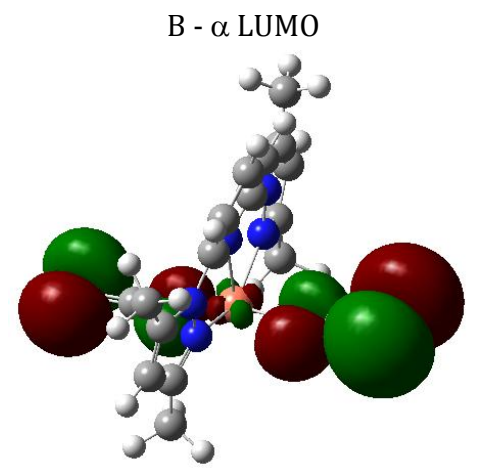

A - $\alpha$ HOMO

Figure 8. A) HOMO and B) LUMO orbitals of $\alpha$ and $\beta$ electrons of the [Cudmpp(SCN)2] complex.

This is due to the fact that the more electrons were withdrawn from the thiocyanide ions the more the triple bond between carbon-nitrogen atoms in thiocyanate ion gets stronger causing the related IR signal shifting towards the higher energies. However, 
there is no such situation in [Cupp(SCN)2] complex. Theoretical IR spectra of two complexes are depicted Figure $9 \mathrm{a}$ and $9 \mathrm{~b}$. The CN triple bond of stretching bands of SCN of [Cupp(SCN)2] and [Cudmpp(SCN)2] appear at $2069 \mathrm{~cm}^{-1}$ and $2121 \mathrm{~cm}^{-1}$ respectively. This is due to the fact that the resonance possibilities are markedly reduced. Similar the signals observed at $1642 \mathrm{~cm}^{-1}$ for [Cupp(SCN)2] and $1643 \mathrm{~cm}^{-1}$ for [Cudmpp(SCN)2] are attributed for the $\mathrm{C}=\mathrm{N}$ stretching in the ring and the signals at $1499 \mathrm{~cm}^{-1}$ and $1487 \mathrm{~cm}^{-1}$ are given for $\mathrm{C}-\mathrm{N}$ stretching in the theoretical spectra. These values are given as 1624 and $1614 \mathrm{~cm}^{-1}$ for stretching of $\mathrm{C}=\mathrm{N}$ and the bands appeared at 1401 and $1404 \mathrm{~cm}^{-1}$ are stretching of C-N bond in the experimental IR spectra. The band expected to appear at $1470 \mathrm{~cm}^{-1}-\mathrm{CH}_{3}-$ bending vibration is not present in the theoretical IR spectra. In spite all these difficulties the theoretical spectra are a quite suitable tool in structural evaluations.

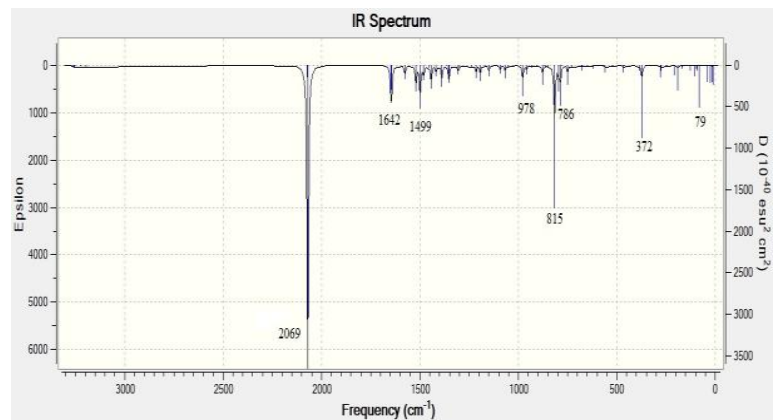

Figure 9a. Theoretical IR spectrum of the [Cupp(SCN)2] complex.

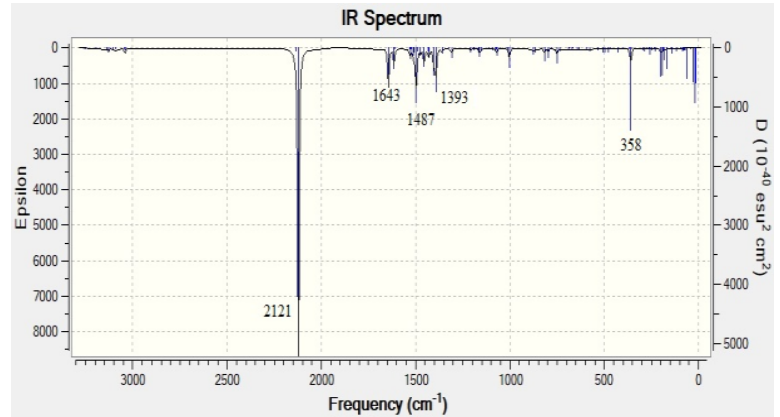

Figure 9b. Theoretical IR spectrum of the [Cupp(SCN)2] complex. The signals below $600 \mathrm{~cm}-1$ were not recorded since the experimental IR spectra were taken by the use of ATR attachment.

Another data obtained by the use of DFT program is the electron densities of the ligands. Table 5 lists the electron densities calculated from the nitrogen donors of the ligands. Note that the electron density on the nitrogen donors of dmpp ligand is higher. This situation shows that dmpp ligand transfers more electrons to [Cudmpp(SCN)2] complex which indicates $\mathrm{Cu}(\mathrm{II})$ ion withdraws lower number of electrons than SCN- ion, that is why the triple bond character of the bond between of $\mathrm{C}$ and $\mathrm{N}$ atoms is less in [Cudmpp(SCN)2] complex. This also explains why the disintegration of [Cudmpp(SCN)2] complex takes place at a temperature $15{ }^{\circ} \mathrm{C}$ higher than [Cupp(SCN)2].
Table 5. The electron density of the donor atoms of the ligand calculated using DFT program.

\begin{tabular}{|l|c|c|}
\hline Donor atom & [Cupp(SCN)2] & [Cudmpp(SCN)2] \\
\hline $\begin{array}{l}\text { N1 (pyrazol ring, } \\
\text { non-coordinated } \\
\text { nitrogen) }\end{array}$ & 0.310 & 0.244 \\
\hline $\begin{array}{l}\text { N2 (pyrazol ring, } \\
\text { coordinated } \\
\text { nitrogen) }\end{array}$ & 0.168 & 0.374 \\
\hline $\begin{array}{l}\text { N3 pyridyne } \\
\text { ring) }\end{array}$ & 0.260 & 0.338 \\
\hline $\begin{array}{l}\text { N4 (pyrazol ring, } \\
\text { non-coordinated } \\
\text { nitrogen) }\end{array}$ & 0.310 & 0.374 \\
\hline $\begin{array}{l}\text { N5 (pyrazol ring, } \\
\text { coordinated } \\
\text { nitrogen) }\end{array}$ & 0.168 & 0.244 \\
\hline
\end{tabular}

\section{References}

[1] Jameson, D. L., Goldsby, K. A. 2,6-bis(Npyrazolyl) pyridines. J. Org. Chem., 55 (1990), 4992-4994.

[2] Palion-Gazda, J., Machura, B., Kruszynski, R., Grancha, T., Moliner, N., Lloret, F., Julve, M. Spin Crossover in Double Salts Containing Six- and Four-Coordinate Cobalt(II) Ions. Inorg. Chem., 56 (2017), 6281-96.

[3] Kruger, C., Augustin, P., Nemec, I., Travnicek, Z., Oshio, H., Boca, R., Renz, F. Spin Crossover in Iron(III) Complexes with Pentadentate Schiff Base Ligands and Pseudohalido Coligands. Eur. J. Inorg. Chem., (2013),905-12.

[4] Broring, M., Kohler, S., Pietzonka, C. Pseudohalogenido complexes of iron-2,2'bidipyrrins. J. Porphyrine and Phatalocyanines, 16 (2012), 641-50.

[5] Nijhuma, M., Samiran, M., Volker, G., S. Ozra, G., Abdul Malik, K. M. Synthesis, characterization and crystal structures of some four coordinated nickel(II) complexes with tridentate Schiff base ligands. Polyhedron, 20 (2001), 135-41.

[6] Kurtaran, R., Odabaşıoğlu, S., Azizoğlu, A., Kara, H., Atakol, 0. Experimental and computational study on [2,6-bis(3,5-dimethyl-N-pyrazolyl) pyridine]-(dithiocyanato)mercury(II). Polyhedron, 26 (2007), 5069-5074.

[7] Arıcı, C., Ülkü, D., Kurtaran, R., Ergun, Ü., Atakol, 0. Crystal Structure Analysis of [bis-2,6-(3,5dimethylpyrazolyl)pyridine-dicyanato] copper(II) monohydrate. Crystal Res. Technol., 41 (2006), 309-313.

[8] Manikandan, P., Thomas, K. R. J., Manoharan, P. T. Structural and spectral diversities in copper(II) complexes of 2,6-bis(3,5-dimethylpyrazol-1-ylmethyl)pyridine]. J. Chem. Soc. Dalton Trans., (2000), 2779-83.

[9] Taştekin, M., Arıcı, C., Svoboda, I., Emregül, K. C., Kurtaran, R., Atakol O., Fuess, H. The Synthesis, 
structure and thermal decomposition of some $\mathrm{Cu}(\mathrm{II})$ complexes with NNN type ligands and thiocyanate anion. Z. Kristallogr., 222 (2007), 255-258.

[10] Grove, H., Julve, M., Lloret, F., Kruger, P.E., Tornroos, K. W., Sletten, J. Syntheses, crystal structures and magnetic properties of copper(II) polynuclear and dinuclear compounds with 2,3bis(2-pyridyl)pyrazine (dpp) and pseudohalide as ligands. Inorg. Chim. Acta., 325 (2001), 115124.

[11] Das, A., Bhattacharya, K., Giri, S., Ghosh, A. Synthesis, crystal structure and magnetic properties of a dinuclear and a trinuclear Ni(II) complexes derived from tetradentate ONNO donor Mannich base ligands. Polyhedron, 134 (2017), 295-301.

[12] Bhargavi, G., Rajasekharan, M. V., Costes, J. P. Synthesis, Crystal Structure and Magnetic Properties of [Mn((1R,2R)-Salcy)N-3/NCS] Complexes: Solvent Dependent Crystallization of Monomers, Chains and Dimers. Chem. Select., 2 (2017), 7975-82.

[13] Sarkar, M., Clerac, R., Mathoniere, C., Hearns, N. G. R., Bertolasi, V., Ray, D. Azido, Cyanato, and Thiocyanato Coordination Induced Distortions in Pentacoordinated [Co(II)A(bip)] (2) (A = NCS, N-3(-), or NCO-) Complexes. Eur. J. Inorg. Chem., 31 (2009), 4675-4685.

[14] Talukder, P., Datta, A., Mitra, S., Rosair, G., El Fallah, M. S., Ribas, J. End-to-end single cyanato and thiocyanato bridged $\mathrm{Cu}$ (II) polymers with a new tridentate Schiff base ligand: Crystal structure and magnetic properties. Dalton Trans., (2004), 4161-67.

[15] Ercan, F., Atakol, O. Crystal structure of a new trinuclear copper(II) complex: $\mathrm{C}_{3} \mathrm{~L}_{2}(\mathrm{SCN})_{2} .2 .5$ $\left(\mathrm{C}_{4} \mathrm{H}_{8} \mathrm{O}_{2}\right)$, Z.Kristallogr., 221 (2006), 735-39.

[16] Ercan, F., Arıcı, C., Ülkü, D., Kurtaran, R., Aksu, M., Atakol, O. Synthesis and Crystal structure of two dimeric Cadmium Complexes bonded with pseudohalides,1.1 and 1.3 bonding. $\mathrm{Z}$. Kristallogr., 219 (2014), 295-99.

[17] Grove, H., Julve, M., Lloret, F., Kruger, P. E., Tornroos, K. W., Sletten, J. Syntheses, crystal structures and magnetic properties of copper(II) polynuclear and dinuclear compounds with 2,3bis(2-pyridyl)pyrazine (dpp) and pseudohalide as ligands. Inorg. Chim. Acta., 325 (2001), 11324.

[18] Diaz, C., Ribas, J., Sanz, N., Solans, X., Font-Bardia, M. Synthesis,Crystal stryucture and Magnetic Properties of catena-poly[(2,2'bipyridylcopper)-di-mü-thiocyanato] and bis (2,2'-bipyridyl)thiocyanatocopper(II) perchlorate. Inorg. Chim. Acta., 286 (199),169-74.
[19] Hazari, A., Giri, S., Diaz, C., Ghosh, A. Unusual site electron of NCS- in trinuclear complexes of $\mathrm{Cu}(\mathrm{II})$ and $\mathrm{Ni}(\mathrm{II})$ with a reduced $\mathrm{N}_{2} \mathrm{O}_{2}$ donor Schiff base. Polyhedron, 118 (2016), 70-80.

[20] Cortes, R., Luiz de Larramendi, J. I., Lezama, L., Rojo, T., Urtiaga, K., Arriortua, M. I. Synthesis, Structural ,Spectroscopic and Magnetic Studies Twoo Azido and Thiocyanato Nickel(II) Dinuclear Complexes with Ferromagnetic Interactions, J. C. S. Dalton Trans., (1993), 272328.

[21] Charlot, M. F., Kahn, O., Chaillet, M., Larrieu, C. Interaction between Copper(II) Ions through the Azido Bridge Concept of Spin Polarization and Abinitio Calculations on Model Systems. J. Am. Chem. Soc., 103 (1986), 2754-81.

[22] Cabort, A., Therrien, B., Bernauer, K., Süss-Fink, G. Copper(II) Azido complexes containing trinitrogen ligands. Inorg. Chim. Acta., 349 (2003), 78-84.

[23] Deoghoria, S., Sain, S., Soler, M., Wong, W. T., Christou, G., Bera, S. K., Chandra, S. K. Synthesis, Crystal Structure and Magnetic Properties of a new Ferromagnetic nickel(II) dimer derived from a hexadentate Schiff Base Ligand. Polyhedron., 22 (2003), 257-62.

[24] Coats, A. W., Redfern, J. P. Kinetic parameters from thermogravimetrical data. Nature, 201 (1964), 68-9.

[25] Ebrahimi, H. P., Hadi, J. S., Abdulnabi, Z. A., Bolandnazar, Z. Spectroscopic, thermal analysis and DFT computational studies of salen-type Schiff base complexes. Spectrochim. Acta Part A, 117 (2014), 485-492.

[26] Ozawa, T. Kinetic Analysis of derivative curves in thermal analysis. J. Therm. Anal., 2 (1970), 301324.

[27] Koga, N. Ozawa's kinetic method for analysing thermoanalytical curves. J. Therm. Anal. Cal., 113 (2013), 1527-1541.

[28] Kissenger, H. E. Reaction Kinetics in Differential Thermal Analysis. Anal.Chem., 29(1957),1702-6.

[29] Frisch, M. J., Trucks, G.W., et al. Gaussian 09, Revision D.01. Gaussian Inc. Wallingford CT. 2009.

[30] Sarada, K., Muraleedharan, K. Effect of addition of silver on the thermal decomposition kinetics of copper oxalate. J. Therm. Anal. Cal., 123 (2016), 643-51.

[31] Çılgl, G. K., Çetişli, H.,Donat, R. Thermal Kinetic analysis of Uranium Salts. J. Therm. Anal. Cal., 115 (2014), 2007-20.

[32] Kullyyakool, S., Danvirutai, C., Siriwong, K., Noisong, P. Determination of kinetic triplet of the synthesized Ni3(P04)2.8H2O by non- 
isothermal and isothermal kinetic methods. J. Therm. Anal. Cal., 115 (2014), 1497-507.

[33] Abdel-Kader, N. S., Amin, R. M., El-Ansary, A. L. Complexes of Schiff base of benzopyran-4-one derivative. J. Therm. Anal. Cal., 123 (2016), 1695-1706.

[34] Wu, B. D., Bi, Y. G., Zhou, M. R., Zhang, T. L, Yang, L., Zhou, Z. N., Zhang, J. G. Stable High Nitrogen Energetic Trinuclear Compounds Based on 4Amino-3,5-dimethyl-1,2,4-Triazole. Z. Anorg. Allg. Chem., 640 (2014), 1467-73.
[35] Ergun, Ü., Atakol, O., Eriş, F. Z., Yücel, ., Düzgün, E. Estimation of Coordination Bond Energies of NH3, H2O and Et2NH Ligands in the Ni(II) and $\mathrm{Cu}$ (II) complexes. J. Therm. Anal. Cal., 97 (2009), 1007-1014.

[36] Addison, A. W., Nageswara Rao, T., Reedijk, J., Van Rijn, J., Verschoor, G. C. Synthesis, Structure and Spectroscopic Properties of Copper(II) Compounds containing Nitrogen-Sulphur Donor Ligands. J. C. S. Dalton Trans., (2001), 3149 3156. 